\title{
Lack of sea urchin settlement may explain kelp forest recovery in overgrazed areas in Norway
}

\author{
Camilla With Fagerli ${ }^{1,2, *}$, Kjell Magnus Norderhaug ${ }^{1,2}{ }^{,}$Hartvig C. Christie ${ }^{1}$ \\ ${ }^{1}$ Norwegian Institute for Water Research (NIVA), 0349 Oslo, Norway \\ ${ }^{2}$ Department of Biology, University of Oslo, Blindern, 0316 Oslo, Norway
}

\begin{abstract}
In this study, we investigated whether failure of sea urchin recruitment can explain an ongoing phase shift from overgrazed, barren grounds to kelp forests along the coast of midNorway. Settlement of sea urchins on artificial substrates deployed in mid-Norway and North Norway was compared on barren grounds and in kelp forests. Settlement varied in time and space, and was low in mid-Norway - the area where kelp is recovering. Settlement did not differ between kelp forest and barren grounds. Densities of adult and juvenile sea urchins were estimated and gonad index (GI) was measured in order to relate sea urchin settlement to local population structure and the reproductive potential of the sea urchin populations. Sea urchin density was generally lower in mid-Norway than in North Norway, but reproductive potential did not differ significantly between the areas. Increasing water temperature is considered a critical factor for sea urchin larval development and may be partly to blame for the recent sea urchin recruitment failure in mid-Norway. Lack of sea urchin recruitment may explain the recovery of kelp in mid-Norway.
\end{abstract}

KEY WORDS: Kelp recovery · Settlement · Recruitment - Sea urchin · Strongylocentrotus droebachiensis · Barren ground · Grazing

\section{INTRODUCTION}

A large-scale ecological shift is occurring along the coastline of mid-Norway. Kelp forests are recovering in the southernmost part of a $2000 \mathrm{~km}^{2}$ area that has been overgrazed by sea urchins. Observations from 2007 confirm that the border between barren ground and kelp forest has moved northwards since the late $1980 \mathrm{~s}$, from $63^{\circ} 30^{\prime} \mathrm{N}$ to $65^{\circ} 30^{\prime} \mathrm{N}$ (Norderhaug \& Christie 2009); kelp forest recovery has been observed in some areas even further north (authors' pers. obs.). The recovery occurs from wave-exposed toward sheltered areas and creates transition areas northwards and inwards. The reason for the recovery is unknown, but appears to be related to the collapse of sea urchin populations. Such population collapses have previously been described from the Norwegian coast, but on a smaller scale (e.g. Christie et al. 1995, Skadsheim et al. 1995), and from other parts of the world (e.g. Tegner \& Dayton 1981, Lessios et al. 1984, Scheibling 1986, Barnes et al. 2002). In the northern part of the barren ground (North Norway), no recovery has been reported and the dominance of sea urchins persists.

During the 1970s, large kelp forest areas, predominantly Laminaria hyperborea (Gunn.) Foslie, suffered destructive grazing by sea urchins Strongylocentrotus droebachiensis (Müller). The event started with a massive increase in sea urchin population density and resulted in barren grounds extending from the coast of mid-Norway $\left(63^{\circ} 30^{\prime} \mathrm{N}\right)$, northwards into Russian waters Sivertsen (1997). Within this area, kelp forests only prevailed in the outer, wave exposed areas (Skadsheim et al. 1995, Sivertsen 1997). Except for some local and temporary regrowth, high densities of sea urchins have prevented the re-establishment of the kelp forests. Sea urchin dominance has now persisted for more than $40 \mathrm{yr}$, causing loss of the high 
productivity and biodiversity associated with kelp forest ecosystems (Christie et al. 2003).

Laminaria hyperborea is found on shallow, rocky substrates, with optimal growth conditions in highlyand moderately wave-exposed subtidal areas (Kain \& Jones 1971). Other kelp species, mainly Saccharina latissima, dominate in more sheltered areas. Sea urchin barrens are predominantly found in sheltered to moderately wave-exposed areas (Sivertsen 1997, Norderhaug \& Christie 2009), and there is an inverse relationship between sea urchin density and wave exposure (Lissner 1983, Witman \& Dayton 2000, Siddon \& Witman 2003). Strongylocentrotus droebachiensis are rare in dense kelp forests (Skadsheim et al. 1995, Steneck et al. 2004), possibly due to a lack of larval settlement, migration or high post-settlement mortality (Hunt \& Scheibling 1997, Connolly \& Roughgarden 1999).

Larval supply, settlement rate and early post-settlement mortality are parameters that commonly limit recruitment of benthic marine invertebrates, and that frequently result in fluctuations in sea urchin populations (Balch \& Scheibling 2001). Strongylocentrotus droebachiensis reproduce annually, have high fecundity, are free spawners with external fertilization, and have a planktonic larval stage lasting 5-21 wk (Strathmann 1978, Hart \& Scheibling 1988) depending on the temperature and initial egg size (Hart \& Scheibling 1988). In the NE Atlantic, mature females are mainly found between February and April, and the main spawning peak is in March (Emlet et al. 1987, Sivertsen 2006). Settlement is concentrated in the summer months (Falk-Petersen \& Lønning 1983). Spawning is probably cued by the spring phytoplankton bloom (Himmelman 1975, 1978, Starr et al. 1990) but is also found to correlate with increasing temperature (Himmelman et al. 2008). However, low temperatures seem favourable for recruitment of $S$. droebachiensis in Norway (Sivertsen 2006) and high temperatures may negatively affect larval development. Stephens (1972) discovered an upper critical limit of $10^{\circ} \mathrm{C}$ for successful development of $S$. droebachiensis larvae. Elevated temperatures due to climate change have been reported to cause redistribution in a variety of marine benthic species (Lindley \& Kirby 2010), including sea urchins (Ling et al. 2008). Higher temperatures may also facilitate the establishment of potential sea urchin predators, which may exert demographic effects on sea urchin populations (Woll et al. 2006, Steneck et al. 2013).

Larval settlement and post-larval recruitment are crucial for the maintenance and perdurability of a sea urchin population. However, the planktonic larval phase makes it difficult to determine how tightly coupled the local adult sea urchin population is to the number of newly recruited sea urchins. Larval dispersal potential is large, and larvae may settle near the parental population (Prado et al. 2012) or disperse far away from it (Underwood \& Fairweather 1989, Miller \& Emlet 1997, Lamare 1998). Some studies indicate that the dispersal distance is primarily determined by coastal topography and currents (Ebert 1996, Gaylord \& Gaines 2000). The Norwegian Coastal Current runs northward along the Norwegian coast with a number of retainment areas along the route. Within these areas, water is partly trapped in retention from 10-50 d (Institute of Marine Research 2007). However, since the abundance of sea urchin larvae is high at shallow depths of between 10 and $15 \mathrm{~m}$ (Miller \& Emlet 1997), tidal fluctuations and wind-generated surface currents will contribute particularly strongly to spatial and inter-annual variation in larval transport. Fjord populations may also be an important source for recruitment to coastal populations, as Strongylocentrotus droebachiensis larvae may be transported from fjords in outflowing surface water (Norderhaug \& Christie 2009).

Overgrazing by sea urchins and phase shifts from kelp forests to barren grounds has been documented worldwide (Dayton 1975, Lawrence 1975, Harrold \& Pearce 1987, Hagen 1995). An alternate stable state may occur on different scales of space and time (Scheibling et al. 1999, Steneck et al. 2002), but the persistence of the barrens reflects the ability of the sea urchins to maintain high abundances (Levitan 1988). Kelp forest rapidly recovers from overgrazing in the absence of sea urchins (Scheibling 1986). Leinaas \& Christie (1996) observed recovery of kelp shortly after experimentally reducing sea urchin density below 10 individuals per square metre on a barren ground area in mid-Norway.

Sea urchin larval supply and settlement rate will naturally vary between years. It is therefore difficult to predict the extent to which a population depends on annual recruitment to maintain its size. Years when recruitment is low could be compensated for by long-lived individuals with an extended reproductive life-span and abundant gamete production. Ebert (1983) suggested that even occasional successful recruitment is sufficient to maintain sea urchin dominance for decades. If wide larval dispersal means that recruitment is decoupled from local population density, one adequate settlement pulse could boost a small population and allow the barren ground state to persist. However, Leinaas \& Christie (1996) documented high adult mortality in barren ground sea urchin populations, suggesting that they 
depend on regular recruitment to maintain high population density. Hence, sufficient recruitment also seems critical for maintenance of the barren ground state - if recruitment is too low, numbers will drop and the population will eventually die out.

In this study, our hypothesis is that settlement has a key function in maintaining sea urchin populations, and we tested this by studying sea urchins in North Norway and mid-Norway. The study areas were separated by more than $800 \mathrm{~km}$ and 5 degrees of latitude. By estimating sea urchin settlement rates, gonad index and density of adult and juvenile sea urchins in the 2 areas, we sought to develop an understanding of (1) how settlement rates of sea urchins compare in North and mid-Norway, (2) how settlement rates compare in kelp forest and on barren ground, (3) how sea urchin settlement is related to sea urchin population density and (4) how the reproductive potential of sea urchin populations is related to settlement. Latitudinal distance between study areas manifests in differing seawater temperature regimes. Since thermal changes may be relevant for sea urchin recruitment patterns, we included historical seawater temperatures (provided by the Norwegian Marine Data Centre at the Institute of Marine Research; www.imr.no/forskning/faggrupper/norsk_marint_dat asenter_nmd/en) in order to study long-term thermal changes.

\section{MATERIALS AND METHODS}

\section{Study areas}

Two study areas within the range of overgrazed barrens were chosen for the study. One was in the waters north of Vega Island at $65^{\circ} 70^{\prime} \mathrm{N}$ in the Norwegian Sea (mid-Norway); the second was located at $70^{\circ} 70^{\prime} \mathrm{N}$ in Hammerfest in the Barents Sea (North Norway) (Fig. 1). Vega Island represents the southern border of the barrens. It is surrounded by an archipelago consisting of a shallow coastal flat dominated by small reefs and islands extending about $50 \mathrm{~km}$ off the coast. Kelp forest has recovered in areas south of Vega, while overgrazed barren grounds still dominate the northern parts of the archipelago (where our stations were located) and northwards (Norderhaug \& Christie 2009, authors' pers. obs.). The second study area, Hammerfest (North Norway), was located in the northernmost part of the barrens, where sea urchins still dominate and no kelp recovery has been reported. Three replicate barren and kelp forest stations in Hammerfest and Vega

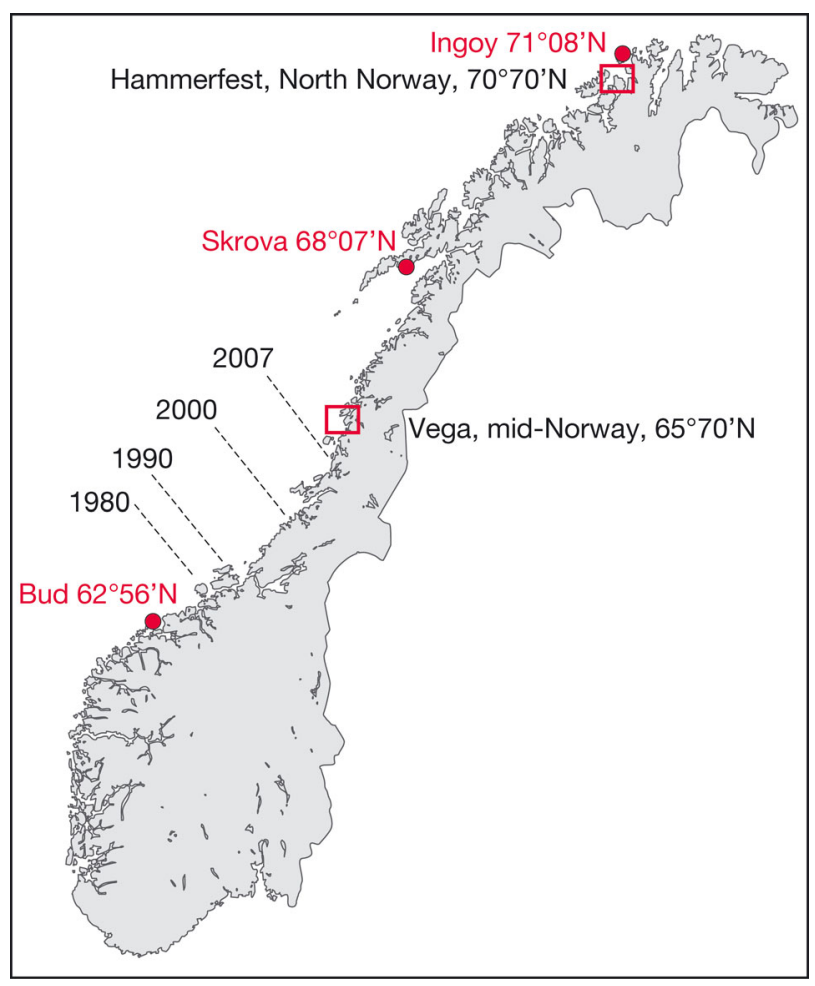

Fig. 1. Norway, showing study areas $(\square)$ and fixed hydrographic stations for long-term temperature measurements (๑). Data provided by Norwegian Marine Data Centre at the Institute of Marine Research. The northward movement of the border between kelp-dominated areas and barren ground are indicated with black dashed lines (from Norderhaug \& Christie 2009). The barren ground encompassed the largest area in 1980 , extending south to $63^{\circ} 30^{\prime} \mathrm{N}$. By 1990 , the border reached $63^{\circ} 40^{\prime} \mathrm{N}$, and in 2000 it was situated at approximately $64^{\circ} 10^{\prime} \mathrm{N}$. In 2007 , the border had moved to $65^{\circ} 30^{\prime} \mathrm{N}$. The current barren ground area extends from midNorway, northward across the Russian border

were used (12 stations in total in a crossed design). The sea floor consists of relatively uniform bedrock with a water depth of approximately $5 \mathrm{~m}$ at high tide at all stations. Kelp forest stations were dominated by a dense canopy of Laminaria hyperborea ( 10 plants $\mathrm{m}^{-2}$ ) with a continuous plant cover along the $5 \mathrm{~m}$ contour. Although the kelp forest had a large spatial extension in both areas (>200 m wide), it appeared more fragmented in Hammerfest. Kelp was absent on sea urchin-dominated barren ground stations.

\section{Sea urchin settlement}

Artificial substrates of various designs have been used successfully in the past to sample newly settled echinoderms that are too small to be sampled in situ (e.g. artificial grass: Balch \& Scheibling 2000, Lambert 
\& Harris 2000; rigid plastic: Tegner 1989; and scrub brushes: Ebert et al. 1994, Hereu et al. 2004). The use of an artificial substrate standardises the volume of the sample and makes it possible to compare settlement quantitatively. We defined sea urchin settlement as the appearance of newly settled individuals (post larvae and early juveniles) (Hernandez et al. 2006) and we used scouring sponges as substrates for sampling. Substrates (5 per station) were deployed at 12 stations in the 2 areas during the settlement season in each of 3 years (2008-2010). Sea urchin settlement rates were measured in the 2 different habitats (kelp forest and barren ground) in both study areas.

At some stations, sampling periods were extended to ensure that the entire settlement season was covered. Table 1 shows the duration of sampling. Vega and Hammerfest are remote areas, which somewhat restricted the sampling frequency. This means that the possibility of some post-settlement mortality, predation and emigration cannot be completely excluded. Scouring sponges were attached to a chain anchored to the bottom by weights to prevent water drag. All sampling was done by SCUBA diving. The settlement substrate was collected and placed separately in sealed plastic bags to prevent loss of newly settled sea urchins. The collected samples were then rinsed with fresh water through a $150 \mu \mathrm{m}$ sieve, and preserved with $5 \%$ buffered formalin. All sea urchins were counted and measured (test diameter) to an accuracy of $0.1 \mathrm{~mm}$ under a dissecting microscope. Although individual growth rates of juveniles may vary (Grieg 1928, Himmelman et al. 1983, Daggett et al. 2005), sea urchins in the size range $0.4-4.0 \mathrm{~mm}$ were considered to have been recruited in the current year.

\section{Sea urchin recruitment}

Juvenile Strongylocentrotus droebachiensis have a cryptic lifestyle, living underneath boulders, gravel and algae to avoid predators (Witman 1985, Himmelman 1986, Raymond \& Scheibling 1987, Scheibling \& Raymond 1990). At the onset of sexual maturity (once individuals reach $\sim 20 \mathrm{~mm}$ in diameter), they become part of the adult population and are found more in the open, moving around actively in search of food (Himmelman 1986, Sivertsen 1997). To compare recruitment of sea urchins at the Vega and Hammerfest study areas and in kelp forest and on barren ground, roof tiles (standardized unit) were deployed at every sampling station as hiding places. Five tiles $(420 \times$ $330 \mathrm{~mm}$ ) were deployed at each station in May 2008. To determine the abundance of recruits, each tile was carefully removed and sea urchins $<20 \mathrm{~mm}$ were counted before the tile was laid gently back into place. The abundance of recruits was recorded in September 2008 and September 2009. Density was given as number of individuals per square metre.

\section{Abundance and reproduction potential of adult sea urchins}

To determine whether variability of sea urchin settlement was associated with variability in the abundance and reproductive potential of adults, we estimated adult population density and gonad index (GI) at our study sites.

The abundance of adult sea urchins was determined by visual counts. Ten frames measuring $0.25 \mathrm{~m}^{2}$ were randomly placed at a depth of $5 \mathrm{~m}$ at each of the sampling stations in May 2008, and adult sea urchins (>20 mm) within each frame were counted. Density was calculated using the average number of Strongylocentrotus droebachiensis within the 10 frames at each station; results are given as number of individuals per square metre. 
A minimum of 30 Strongylocentrotus droebachensis were collected from each barren ground sampling station at both study areas in September 2009-a time of year when the gonads are still developing (Meidel \& Scheibling 1998). The sea urchins were sampled within $0.25 \mathrm{~m}^{2}$ quadrats randomly dropped from 1-2 $m$ above the sea floor, until a sample size of 30 was reached. All sea urchins within the last quadrat were collected, to gain a representative sample of the population. Since GI varies with test size in smaller individuals (Stien et al. 1998), large individuals (>40 mm test diameter) were chosen for comparison between stations and study areas. The sea urchins were processed live, immediately after sampling. Test diameter was measured to the nearest $0.5 \mathrm{~mm}$ using vernier callipers, and total body weight and gonad weight were measured electronically to an accuracy of $0.1 \mathrm{~g}$. The sea urchin and dissected gonads were carefully dried off with a paper towel before weighing (wet weight). GI was calculated according to Keats et al. (1984) as (gonad wet weight/ total body wet weight) $\times 100$.

Maximum June temperatures recorded at $10 \mathrm{~m}$ depth between 1972 and 2010 at 3 stations in Norway were included to relate sea urchin recruitment and kelp forest recovery to changes in temperature. Temperatures exceeding critical thresholds for successful larval development will result in recruitment failure. The temperature data were provided by the Norwegian Marine Data Center at Institute of Marine Research.

\section{Data analysis}

All statistical analysis was performed with R 2.15.0 (www.r-project.org).

To analyse the variability in sea urchin settlement (newly recruited sea urchins from 5 replicate settlement substrates), we used a generalized linear mixed model (GLMM). Because sampling was repeated over 3 years, we included a dependence structure by using station as a random factor. The explanatory factors study area, habitat, year and days of exposure were included as fixed effects. Days of exposure was included in the model as a continuous variable to control for the effect of the differing duration of exposure of settlement substrates between areas and years. All possible interactions were included in a full model. Akaike's Information Criterion (AIC) was used as a tool for model selection, and the candidate models were ranked relative to each other. The 'Ime4' package (Bates et al. 2011) was used for the analysis as it allowed for a Poisson-distributed response variable and random effects. Only samples from July were included in the statistical analysis, since settlement peaked during this month.

Difference in GI of Strongylocentrotus droebachiensis populations from barren ground in Vega were compared to the populations found on barren ground stations in Hammerfest using a linear mixed effect model ('lmer') from the 'nlme' package (Pinheiro et al. 2012). Explanatory variables included in the model were area (fixed effect with 2 levels) and station (random effect with 6 levels). GI values were square-root transformed to achieve homogeneity of variance.

June maximum sea water temperatures were used in simple regression analysis to detect significant changes in sea water temperature. In June, the Strongylocentrotus droebachiensis larvae are developing, temperatures are high and may exceed the larvae's tolerance limit $\left(>10^{\circ} \mathrm{C}_{i}\right.$ Stephens 1972). The number of June temperature measurements ranged between 1 and 5 measurements $\mathrm{yr}^{-1}$.

\section{RESULTS}

\section{Variability in sea urchin settlement}

There was a pronounced settlement peak in July; more than $90 \%$ of all new recruits were found in samples from July. The settlement rate of sea urchins was significantly lower in mid-Norway (Vega) than in North Norway (Hammerfest) (Table 2, Fig. 2). Only 4 newly settled sea urchins

Table 2. Parameter estimates, standard error (SE) estimates and pvalues for the predictors in the generalized linear mixed model (GLMM) selected by Akaike's Information Criterion (AIC)

\begin{tabular}{|lrrr|}
\hline Fixed effects & $\begin{array}{c}\text { Parameter } \\
\text { estimate }\end{array}$ & SE & \multicolumn{1}{c|}{$\mathrm{p}$} \\
\hline Intercept & -6.94 & 5.11 & 0.17 \\
Area (Hammerfest = 0, Vega = 1) & -2.50 & 0.98 & $<0.05$ \\
Habitat (Barren = 0, Kelp = 1) & -0.15 & 0.63 & 0.80 \\
Year (2008 = 0, 2009=1) & -0.39 & 0.58 & 0.51 \\
Year (2008 = 0, 2010 = 1) & -2.03 & 0.92 & $<0.05$ \\
Days of exposure & 0.13 & 0.08 & 0.11 \\
Area: Habitat & -14.26 & 909.87 & 0.98 \\
Habitat: Year 2009 & -0.43 & 0.27 & 0.12 \\
Habitat: Year 2010 & 0.45 & 0.31 & 0.15 \\
\hline
\end{tabular}


were found in settlement substrates from Vega during 3 years of sampling $(n=75)$ compared to substrates from Hammerfest, where 311 sea urchins were found during the same period $(\mathrm{n}=85)$ A period of settlement was not recorded at 2 stations in Vega (Stn V4 in 2009 and Stn V6 in 2010), which resulted in different replicate numbers between the two study sites. The settlement rate varied significantly between years; sea urchins settled in greater numbers in July 2008 than in July 2010 (Table 2).

The analysis showed no significant difference in sea urchin settlement between kelp and barren ground habitats, although no settlement was recorded at the Vega kelp forest stations (Table 2, Fig. 2). There was wide local variation; many samples contained no sea urchins, and variation at even the smallest spatial scale was large (Fig. 2). The effect of different exposure time on settlement substrates was not significant (Table 2).

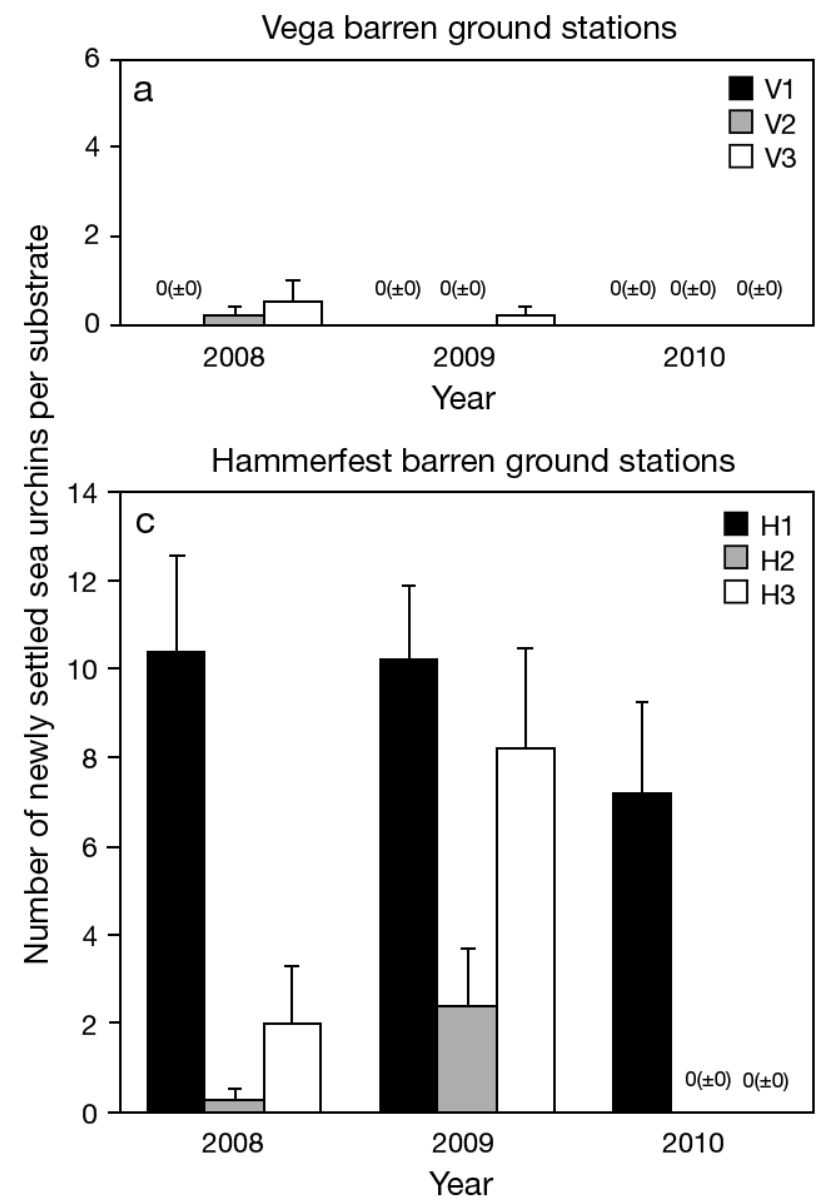

\section{Abundance of sea urchin recruits}

Sea urchins $<20 \mathrm{~mm}$ were present at all barren ground sampling stations at both study areas in 2008, while no recruits were found at Vega Stn V1 in 2009. At the Hammerfest study area, the highest abundance (mean $\pm \mathrm{SE}$ ) of recruits at barren ground stations was observed at Stn H2 in 2009 (92.4 \pm 41.32); in kelp forest, abundance was highest at Stn H6 in $2008(14 \pm 7)$. No recruits were observed at Stn H6 in 2009. At the Vega study area, abundance of recruits was highest at Stn V3 in 2009 (38.5 \pm 25.7). At the other Vega barren ground stations, mean $( \pm \mathrm{SE})$ densities ranged from 0 to $10.5( \pm 7.4)$. No recruits were observed at kelp forest sites in Vega, with the exception of a small number at Stn V6 in 2009 (1.75 \pm 0.88) (Fig. 3). The abundance of recruits was higher at barren ground stations in Hammerfest than in Vega (Fig. 3). Overall, recruits were more abundant on barren ground than in kelp

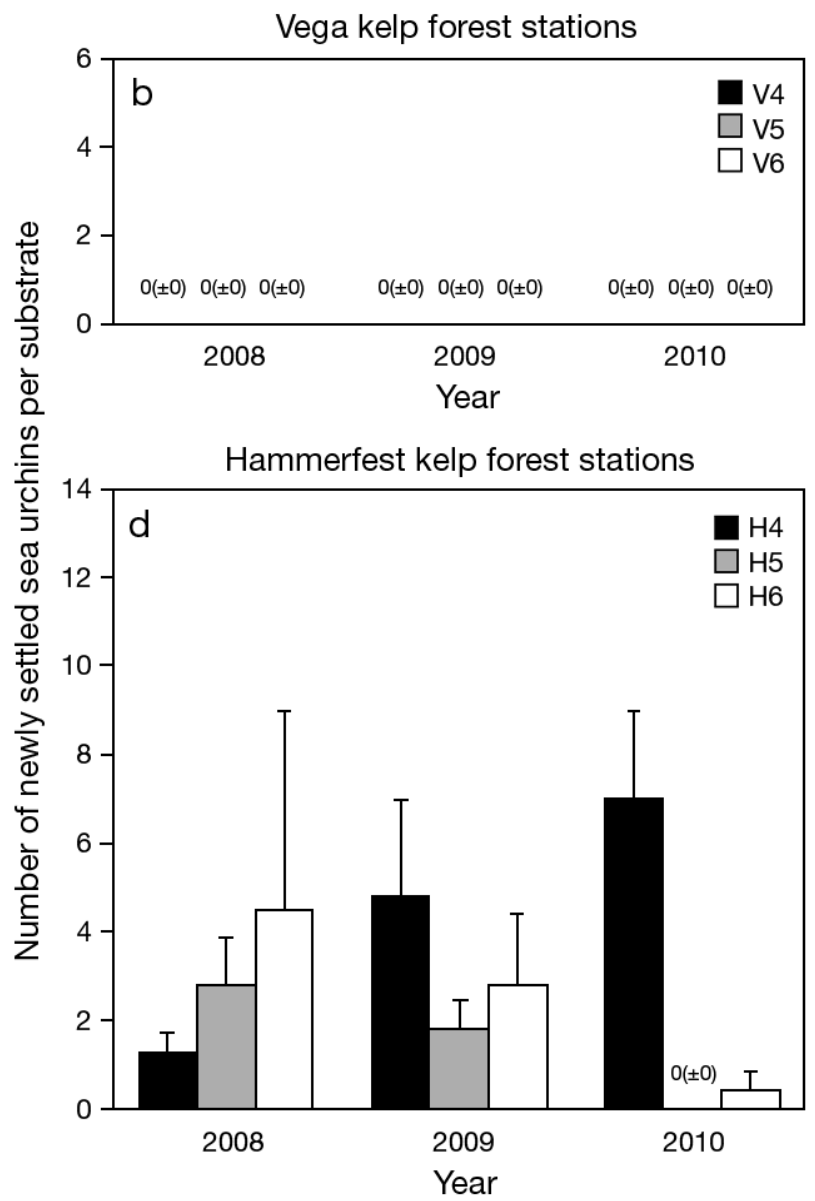

Fig. 2. Strongylocentrotus droebachiensis. Mean $( \pm \mathrm{SE})$ density of recently settled sea urchins per settlement substrate sampled from barren ground and kelp forest stations in mid-Norway (Vega; Stns V1-V6) and North Norway (Hammerfest; Stns H1-H6) in July 2008-2010 

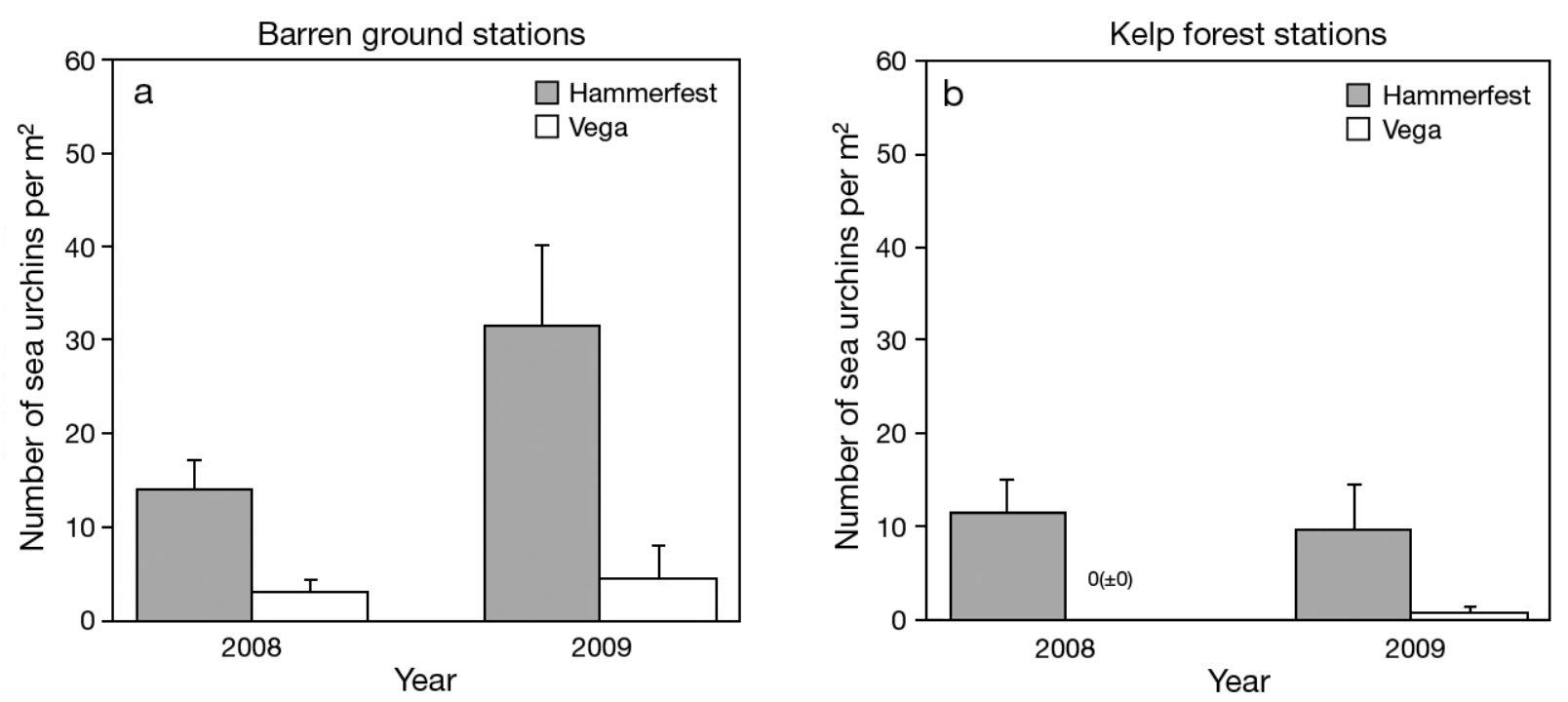

Fig. 3. Strongylocentrotus droebachiensis. Mean $( \pm \mathrm{SE})$ density (ind. $\left.\mathrm{m}^{-2}\right)$ of juveniles $(<20 \mathrm{~mm})$ in North Norway (Hammerfest) and mid-Norway (Vega) on barren ground and kelp forest stations from September 2008 and 2009

forest, and more abundant in 2009 than in 2008 (Fig. 3).

\section{Abundance and reproduction potential of adult sea urchins}

At the Vega study area, adult sea urchins were present at low densities on barren ground and absent from kelp forest. In contrast, they were generally abundant in Hammerfest, both on barren ground and at 2 of 3 kelp forest stations (Fig. 4). While mean $( \pm \mathrm{SE})$ adult density ranged from $4.8( \pm 0.8)$ to $17.2( \pm 3)$ on barren ground stations in Vega, corresponding densities from barren ground stations in Hammerfest ranged from $25.2( \pm 6.3)$ to $58( \pm 8.6)$. There was no correlation between sea urchin settlement and local abundance of adult sea urchins (Fig. 5a), nor between sea urchin settlement and GI (Fig. 5b). The GI of Strongylocentrotus droebachien-

sis from barren ground populations in Vega was not significantly different from that of barren ground sea urchins in Hammerfest (Table 3). There was non-systematic, local variability between stations, and individuals from Stns V1 and H2 had lower GI values than those from other stations (Fig. 6).

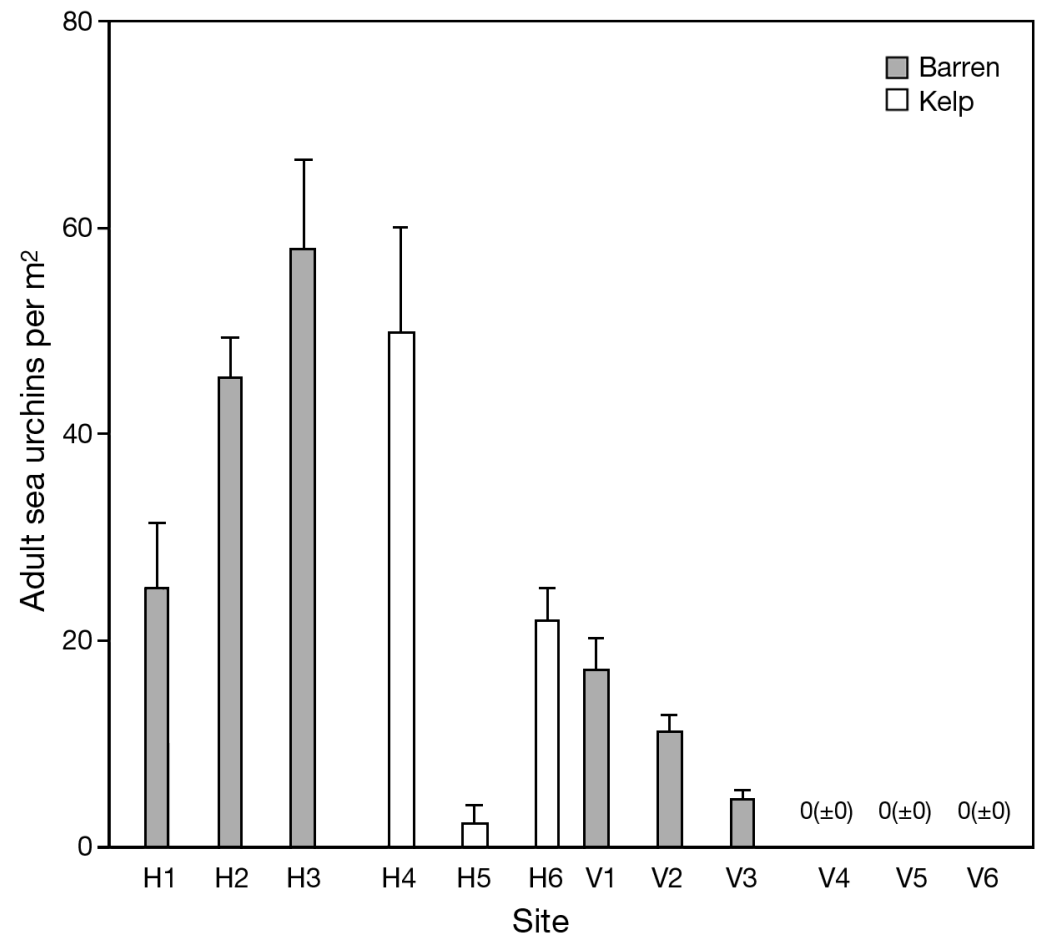

Fig. 4. Strongylocentrotus droebachiensis. Mean number ( \pm SE) of adults (ind. $\mathrm{m}^{-2}$ ) from 6 sampling stations in North Norway (Hammerfest Stns H1-H6) and 6 in mid-Norway (Vega Stns V1-V6). Recorded from quadrats; $\mathrm{n}=10 \mathrm{site}^{-1}$

Fig. 7 shows an increase in June water temperature between 1972 and 2010 at the 3 stations. Temperature correlates clearly with latitude, with the highest temperature recorded at the southernmost station. The increase in water temperature was significant at all stations (Table 4). 


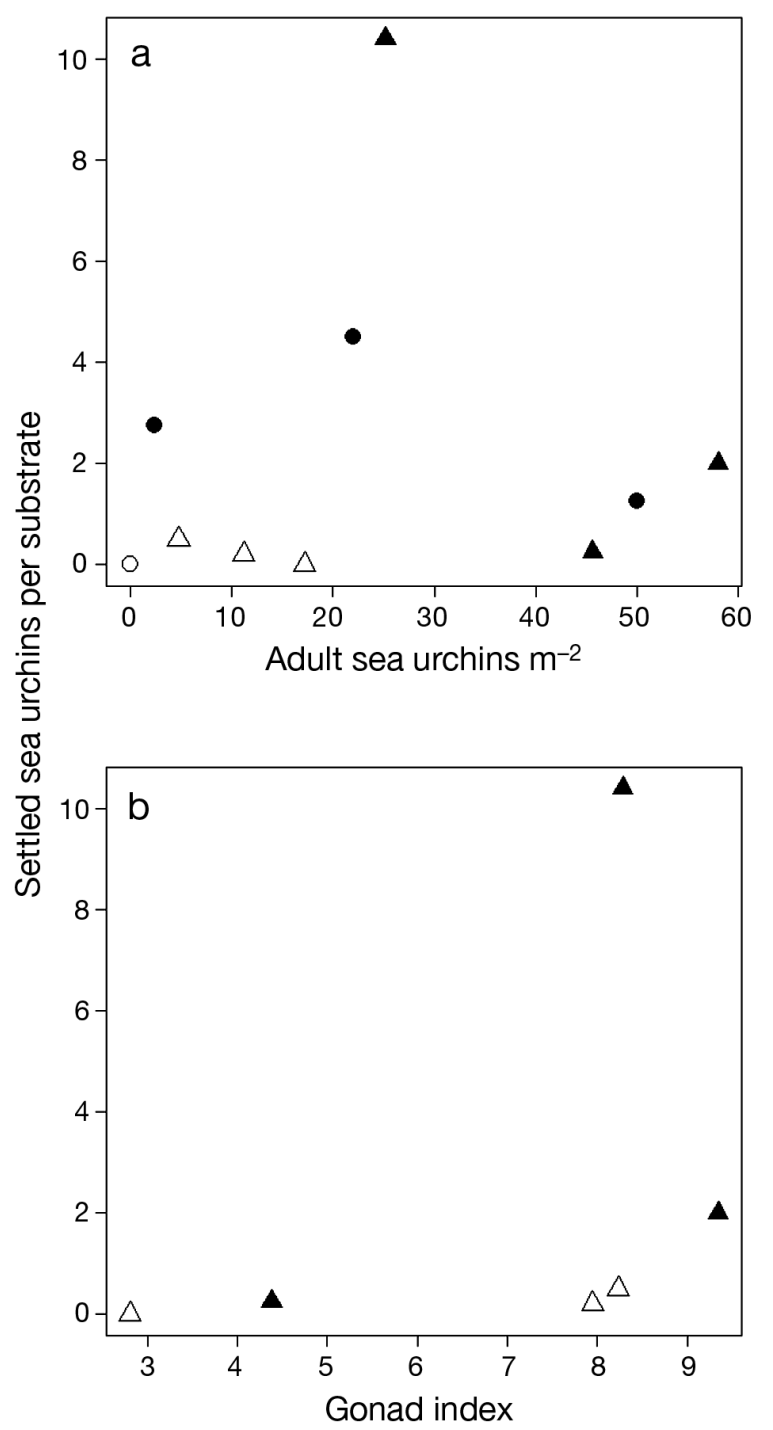

Fig. 5. Number of newly settled sea urchins collected from settlement substrates in July 2008 and adult sea urchin (a) density (estimated in May 2008), and (b) gonad index (estimated in September 2009). $\mathbf{\Delta}$ : Hammerfest barren ground; -: Hammerfest kelp forest; $\Delta$ : Vega barren ground; O: Vega kelp forest

Table 3. Parameter estimates, standard error (SE) estimates, and $\mathrm{p}$-values for the linear mixed effect model comparing gonad index between sea urchin Strongylocentrotus droebachiensis populations from Hammerfest (North Norway) and Vega (mid-Norway); $\mathrm{n}=183$ individuals

\begin{tabular}{|lrrr|}
\hline Fixed effects & $\begin{array}{c}\text { Parameter } \\
\text { estimate }\end{array}$ & SE & $\mathrm{p}$ \\
\hline Intercept & 2.52 & 0.38 & 0.00 \\
Area (Hammerfest $=0$, Vega $=1)$ & -0.19 & 0.54 & 0.75 \\
\hline
\end{tabular}

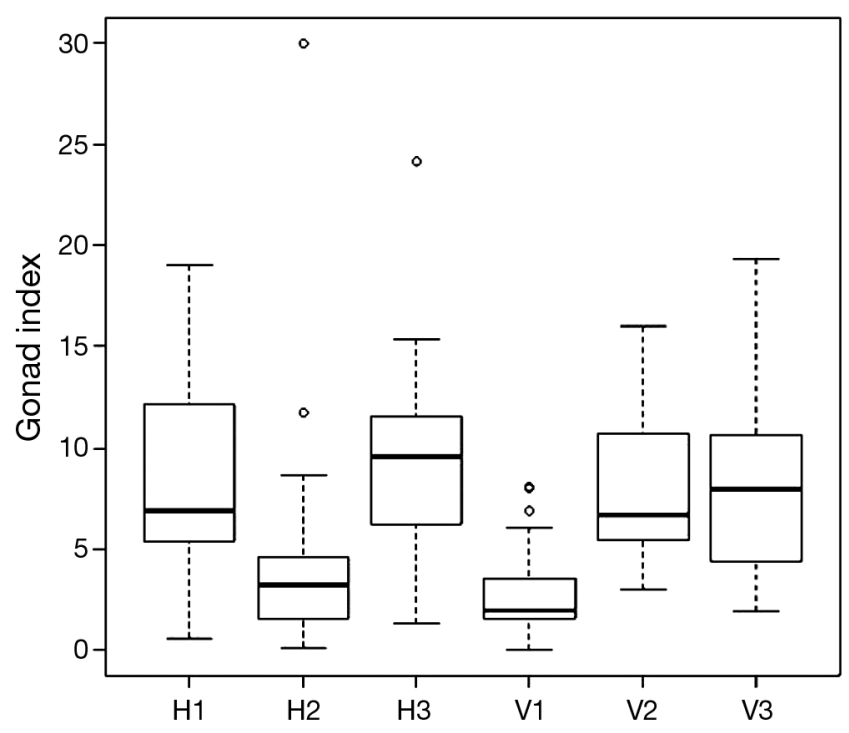

Fig. 6. Strongylocentrotus droebachiensis. Between-station comparison of reproductive potential (gonad index), estimated from 183 individuals sampled from quadrats at Hammerfest (Stns H1-H3) and Vega (Stns V1-V3). Boxes: lower and upper quartiles; lines: median value; whiskers: 5 th and 95th percentiles; circles: outliers

\section{DISCUSSION}

The current collapse in the sea urchin Strongylocentrotus droebachiensis population and recovery of kelp forests in mid-Norway may be attributed to failure of sea urchin settlement. There was a significant difference between Vega and Hammerfest in settlement rates; virtually no settlement was observed in Vega during the entire study period. In northern Norway (Hammerfest), newly settled sea urchins were found both at barren ground and in kelp forest stations in all 3 sampling years, although with significant inter-annual variation.

Ocean temperature may play an important part in explaining the lack of settlement in Vega. Development of echinoderm larvae is temperature-dependent, with increasing growth and metabolic rate occurring at higher temperatures (Turner 1965, Strathmann 1978, McEdward 1985, Hart \& Scheibling 1988). Changes in species distribution in response to ocean warming and climate change have been well documented, and larger-scale changes are expected in the years ahead (Hughes 2000, Walther et al. 2002, Harley et al. 2006, Parmesan 2006). Ling et al. (2008) explain the range expansion and establishment of the sea urchin Centrostephanus rodgersii in eastern Tasmania as a response to high water temperature, as temperatures in eastern Tasmanian waters have risen 


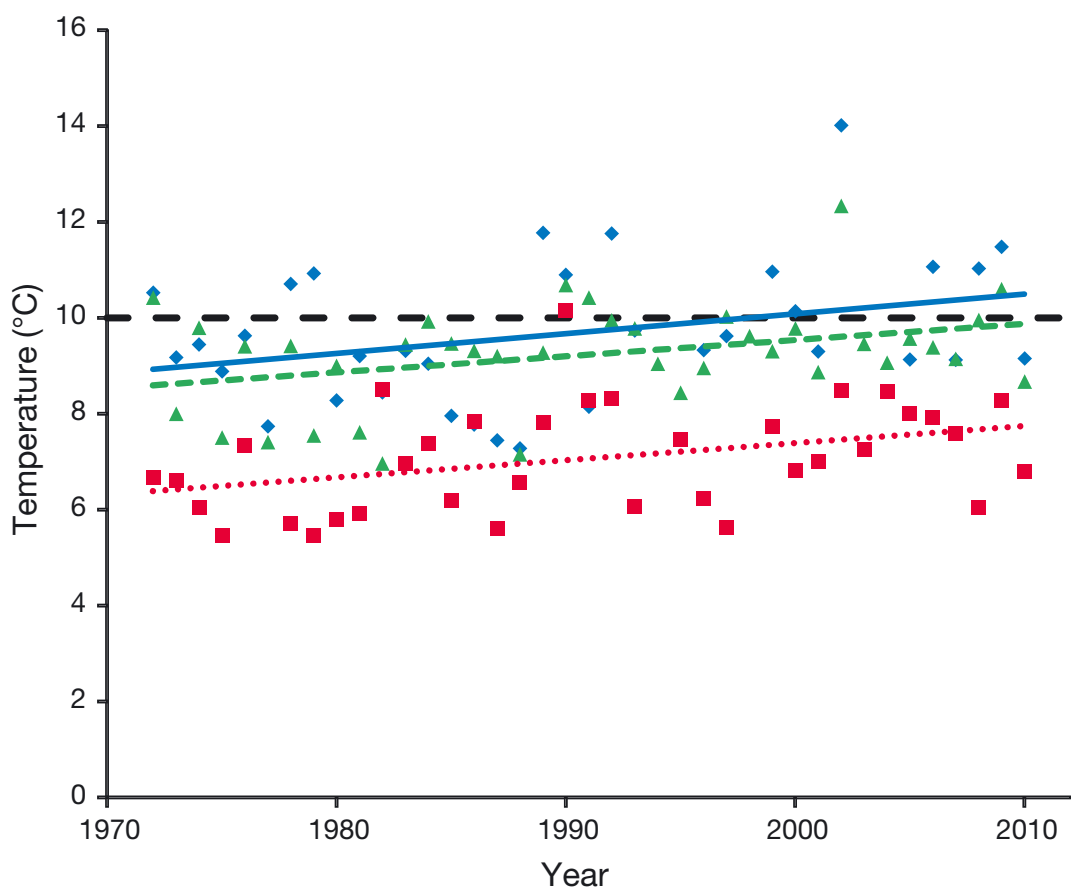

Fig. 7. Long-term June maximum water temperature (1972-2010), measured

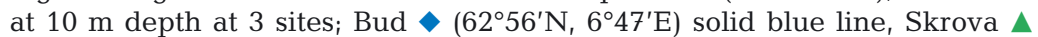
$\left(68^{\circ} 07^{\prime} \mathrm{N}, 14^{\circ} 39^{\prime} \mathrm{E}\right)$ dashed green line, and Ingøy $\left(71^{\circ} 08^{\prime} \mathrm{N}, 24^{\circ} 01^{\prime} \mathrm{E}\right)$ dotted red line. Data provided by the Norwegian Marine Data Centre at the Institute of Marine Research. Black dashed line: critical temperature for inhibition of sea urchin larval development $\left(10^{\circ} \mathrm{C}\right.$; Stephens 1972)

Table 4. Linear relationship between maximum June seawater temperatures and year (1972-2010) from 3 locations in Norway

\begin{tabular}{|lcccc|}
\hline Location (lat.) & $\mathrm{R}^{2}$ & $F$ & $\mathrm{p}$ & Equation \\
\hline Bud $\left(62^{\circ} 56^{\prime} \mathrm{N}\right)$ & 0.08 & 3.87 & 0.05 & $0.0412 x-72.33$ \\
Skrova $\left(68^{\circ} 07^{\prime} \mathrm{N}\right)$ & 0.10 & 5.41 & 0.02 & $0.0337 x-57.93$ \\
Ingoy $\left(71^{\circ} 08^{\prime} \mathrm{N}\right)$ & 0.11 & 5.43 & 0.03 & $0.0357 x-63.99$ \\
\hline
\end{tabular}

above the sea urchin's physiological threshold for successful larval development. Climate change may also affect abundances of important habitat-forming species, with repercussions for entire ecosystems. Recruitment of the destructive grazer Diadema aff. antillarum is positively correlated with seawater temperature, and a further ocean warming may threaten the stability of macroalgal beds around the Canary Islands through growing sea urchin populations (Hernandez et al. 2010). However, thermal tolerance varies from one species to another. Stephens (1972) reports that the critical upper limit for normal development of Strongylocentrotus droebachiensis larvae is $10^{\circ} \mathrm{C}$, and suggests that temperature would limit the southward distribution of $S$. droebachiensis in the
NW Atlantic. From samples of echinoderm larvae in the NE Atlantic, Sivertsen (2006) proposes a correlation between low temperatures and high abundance of echinoderm larvae in Norway. Summer temperatures from 3 locations in Norway (provided by the Norwegian Marine Data Centre at the Institute of Marine Research) show a significant increase in sea temperature between 1972 and 2010, with increasing incidence of maximum temperatures above $10^{\circ} \mathrm{C}$ (Fig. 7). Since there is a north-south gradient in ocean temperature along the Norwegian coast, sea urchin larvae in the Hammerfest study area live in colder water than those in Vega. With continued global warming, one could expect further reduction in $S$. droebachiensis recruitment northwards, and potential kelp recovery.

The Hammerfest stations received a steady supply of sea urchin settlers, although with local and inter-annual variation. Fluctuations in hydrological parameters, such as wind-generated currents and wave action (Ebert \& Russell 1988, Balch et al. 1999) and the presence of predators and conspecifics (Tegner \& Dayton 1981, Roy et al. 2012) are some of the factors planktonic sea urchin larvae respond to, and that contribute to patchiness in settlement (Rodriguez et al. 1993). Local topographical features and current regimes may also explain the remaining patches of sea urchin-dominated barrens within the regrowth area in mid-Norway (see Norderhaug \& Christie 2009). Echinoderm larvae may accumulate in sheltered bays and the lee of reefs, intensifying settlement in retention areas (Pedrotti \& Fenaux 1992, Sewell \& Watson 1993).

Coralline algae, microbial films and conspecifics have been shown to induce settlement of sea urchin larvae (Pearce \& Scheibling 1990, 1991, Scheibling \& Robinson 2008). Balch \& Scheibling (2000) observed greater recruitment of Strongylocentrotus droebachiensis in barren ground than in kelp forest, whereas McNaught (1999), Rowley (1989) and Schroeter et al. (1996) found no such habitat-specific differences. In our study, there were no significant differences between the densities of newly settled sea urchins at the kelp forest and barren ground stations in Hammerfest. At Vega, there were only very small num- 
bers of newly settled sea urchins in barren ground habitats, and no settlement in kelp forest (Fig. 2). Hence, sea urchin settlement does not seem to explain the pattern and distribution of kelp forest and sea urchin-dominated barren grounds in our 2 study areas.

Newly settled sea urchins are often subject to high post-settlement mortality which makes it difficult to predict how well settlement reflects early recruitment (Hunt \& Scheibling 1997, Connolly \& Roughgarden 1999). In a study of factors that may regulate sea urchin populations in Maine, McNaught (1999) found that post-settlement mortality from micropredators was higher in kelp beds than on barren ground. He suggested that high predation intensity in the kelp community has a positive feedback effect on the state of the kelp forest, and may be necessary for its persistence. Our settlement substrates were exposed for relatively long periods (Table 1) and did not exclude potential predators. Early post-settlement mortality affects sea urchin recruitment and might have influenced our results, potentially explaining the lack of sea urchin settlement in Vega. It could also mean that we underestimated the settlement rate in Hammerfest. If post-settlement survival is lower in Hammerfest kelp forests than on barren ground, predation may be important in order to explain patterns of remaining kelp forests in this area. Thus, we cannot exclude micropredation as a possible additional factor explaining our results in either study area, but the results show that failure of sea urchin recruitment is probably the ultimate explanation for kelp recovery in mid-Norway, regardless of whether larval mortality or post-settlement mortality is the causal factor.

Despite the low settlement rates in Vega, juvenile Strongylocentrotus droebachiensis were found at all the barren ground stations (Stns V1-V3) in 2008, indicating that there is at least sporadic recruitment. However, compared with earlier studies (Skadsheim et al. 1995, Leinaas \& Christie 1996), our results indicate that sea urchin density in barren ground habitats has decreased in mid-Norway. Additionally, densities of juveniles in Vega were low compared to densities in Hammerfest (Fig. 3).

Adult Strongylocentrotus droebachiensis are seldom found in dense kelp forests (Hjorleifsson et al. 1995, Skadsheim et al. 1995) and were not found at the Vega kelp forest stations (Fig. 4). Their absence from kelp forest may reflect a higher mortality rate there than on barren ground. Although kelp provides food and shelter, a high predation risk may outweigh these benefits (McNaught 1999). The structurally complex kelp forests provide habitat for a diverse invertebrate community (Dayton 1985, Norderhaug et al. 2002, Christie et al. 2003), including high densities of micropredators (McNaught 1999) and fish (Norderhaug et al. 2005). Predation intensity on benthic life stages is thus expected to be higher inside a kelp forest than in barren areas, which have low biological diversity and are structurally simple (Steneck et al. 2013). Micropredators may decimate entire cohorts of settled sea urchins inside kelp forests (Rowley 1989, McNaught 1999).

The abundance of juvenile sea urchins was generally higher at barren ground stations than at kelp forest stations in Hammerfest, but adult densities in kelp forest were surprisingly high and differed little from those at barren ground stations. As mentioned above, adult sea urchins are naturally scarce inside kelp forests, but abundance in Hammerfest was $>20 \mathrm{~m}^{-2}$ at 2 of $3 \mathrm{kelp}$ forest stations (Fig. 4). We observed heavy grazing and variation in the distribution of kelp forest and barrens at the Hammerfest stations during this 3year study, and the system seems to be ecologically unstable. It has been suggested that over-exploitation of sea urchin predators and the resulting low predation pressure promotes a phase shift from kelp forest to barren ground (Steneck et al. 2002, 2004, Ling et al. 2009). Juvenile sea urchins may be vulnerable to a variety of predators from which the adults can escape (Clemente et al. 2013). Bimodal size structures in Strongylocentrotus droebachiensis populations, where cryptic juveniles (with spatial refuge) and adults (with a size refuge) are more commonly represented than exposed intermediate-sized individuals, is not unusual (Scheibling 1986, 1996). If predation pressure on adult sea urchins is reduced (for example because populations of large predatory fishes decline), sea urchins could also avoid the threat from predators by spending their juvenile life on barren ground and migrating into kelp forests when their nutritional demand increases. The kelp and barren ground stations were closer together in Hammerfest than in Vega, which would facilitate such a migration.

Low reproductive potential cannot explain the low recruitment of sea urchins in Vega. The linear mixed effect model revealed no significant differences in GI between sea urchins on barren grounds in Hammerfest and in Vega (Table 2). There was local variability between stations (Fig. 6); individuals from Stns V1 and H2 had lower mean GI than those from the other stations. This may suggest that factors promoting local differences (e.g. habitat characteristics such as food quality and sea urchin density) better explain 
the variation than geographical differences (e.g. temperature). Sea urchin GI responds to algal food quality and availability (Vadas 1977, Leinaas \& Christie 1996) and the distance from algal food sources may also cause variation. It has been found that GI decreases with increasing distance from kelp beds, as drift algal subsidies decrease (Kelly et al. 2012). Laminaria hyperborea in mid-Norway have higher growth and turnover rates compared to individuals further north (Rinde \& Sjøtun 2005). High densities of sea urchins increase competition for food resources, and also affect GI (Wahle \& Peckham 1999). From our estimates of GI levels, it does not appear that sea urchins at the Vega study area are benefitting either from a higher kelp production or from lower sea urchin population density than in the Hammerfest area, although this may be because there is generally good access to food in Hammerfest. From a density perspective, however, the larval pool produced in Vega may be smaller compared to the larval pool in Hammerfest if fertilization success correlates with density of sexually mature adults as proposed by Levitan et al. (1992) and Pennington (1985). LauzonGuay \& Scheibling (2007) argued, however, that population size is far more important than population density in order to obtain high fertilization rates. Although adult density has declined, the distribution of the remaining sea urchin population in mid-Norway is still widespread and has high reproductive potential, allowing for a substantial contribution of gametes to the overall larval pool.

The absence of newly settled sea urchins in Vega suggests that low settlement rates (or high early postsettlement mortality) have an important influence on the population structure of Strongylocentrotus droebachiensis. Since the ocean temperature has been rising during the kelp recovery period, it is tempting to suggest that there is a relationship between high temperature and recruitment failure of $S$. droebachiensis. Temperature changes are affecting whole ecosystems, and many marine benthic species have shifted their distribution further northwards (Lindley \& Kirby 2010). Changes in the marine fauna may indirectly affect kelp-urchin dynamics as new, potential sea urchin predators may become established. For example, the abundance of the edible crab Cancer pagurus has increased in the kelp recovery area in mid-Norway. Close relatives of this crab species have turned out to be important sea urchin predators in other areas (Himmelman \& Steele 1971, Siddon \& Witman 2004, McKay \& Heck 2008, Steneck et al. 2013), so C. pagurus may also prove to be a threat to $S$. droebachiensis.
In summary, sea urchin density has decreased on remaining barren ground habitats in mid-Norway, approaching the threshold for the regrowth of kelp (see Leinaas \& Christie 1996). Thus, a scenario with further kelp recovery seems likely if sea urchin recruitment remains low. However, our results (linked with long-term temperature monitoring data) suggest that elevated temperatures may also be a necessary condition for sea urchin recruitment failure and kelp recovery.

Acknowledgements. We thank S. Fredriksen, M. Foldager Pedersen, S. Nilsen, K. Dahl and L. Bjørn Mehus for their assistance in sampling sea urchins. H. Gundersen gave valuable statistical help and the Institute of Marine Research provided temperature data. This study was funded by the Research Council of Norway and NIVA as part of the project 'Habitat restoration in overgrazed areas on the northern Norwegian coast'.

\section{LITERATURE CITED}

Balch T, Scheibling RE (2000) Temporal and spatial variability in settlement and recruitment of echinoderms in kelp beds and barrens in Nova Scotia. Mar Ecol Prog Ser 205:139-154

Balch T, Scheibling RE (2001) Larval supply, settlement and recruitment in echinoderms. In: Lawrence JM, Jangoux M (eds) Echinoderm studies, Vol 6. Balkema, Lisse, p 1-83

Balch T, Hatcher BG, Scheibling RE (1999) A major settlement event associated with minor meteorologic and oceanographic fluctuations. Can J Zool 77:1657-1662

> Barnes DKA, Verling E, Crook A, Davidson I, O'Mahoney M (2002) Local population disappearance follows (20 yr after) cycle collapse in a pivotal ecological species. Mar Ecol Prog Ser 226:311-313

Bates D, Maechler M, Bolker B (2011) lme4: linear mixedeffects models using $\mathrm{S} 4$ classes. $\mathrm{R}$ package version 0.999375-42. http://CRAN.R-project.org/package=lme4

Christie H, Leinaas HP, Skadsheim A (1995) Local patterns in mortality of the green sea urchin, Strongylocentrotus droebachiensis, at the Norwegian coast. In: Skjoldal HR, Hopkins C, Erikstad KE, Leinaas HP (eds) Ecology of fjords and coastal waters. Elsevier Science, Amsterdam, p 573-584

Christie H, Jorgensen NM, Norderhaug KM, WaageNielsen E (2003) Species distribution and habitat exploitation of fauna associated with kelp (Laminaria hyperborea) along the Norwegian coast. J Mar Biol Assoc UK 83:687-699

> Clemente S, Hernández JC, Montaño-Moctezuma G, Russel MP, Ebert TA (2013) Predators of juvenile sea urchins and the effect of habitat refuges. Mar Biol 160:579-590

Connolly SR, Roughgarden J (1999) Theory of marine communities: competition, predation, and recruitmentdependent interaction strength. Ecol Monogr 69:277-296

Daggett TL, Pearce CM, Tingley M, Robinson SMC, Chopin T (2005) Effect of prepared and macroalgal diets and seed stock source on somatic growth of juvenile green sea urchins (Strongylocentrotus droebachiensis). 
Aquaculture 244:263-281

Dayton PK (1975) Experimental studies of algal canopy interactions in a sea otter dominated kelp community at Amchitka Island, Alaska. Fish Bull 73:230-237

$>$ Dayton PK (1985) Ecology of kelp communities. Annu Rev Ecol Syst 16:215-245

Ebert TA (1983) Recruitment in echinoderms. In: Jangoux M, Lawrence JM (eds) Echinoderm studies, Vol 1. Balkema, Rotterdam, p 169-201

Ebert TA (1996) The consequences of broadcasting, brooding, and asexual reproduction in echinoderm metapopulations. Oceanol Acta 19:217-226

$>$ Ebert TA, Russell MP (1988) Latitudinal variation in size structure of the west coast purple sea urchin: a correlation with headlands. Limnol Oceanogr 33:286-294

Ebert TA, Schroeter SC, Dixon JD, Kalvass P (1994) Settlement pattern of red and purple sea urchins (Strongylocentrotus franciscanus and Strongylocentrotus purpuratus) in California, USA. Mar Ecol Prog Ser 111:41-52

Emlet RB, McEdward LR, Strathmann RR (1987) Echinoderm larval ecology viewed from the egg. In: Jangoux M, Lawrence JM (eds) Echinoderm studies, Vol 2. Balkema, Rotterdam, p 55-136

Falk-Petersen IB, Lønning S (1983) Reproductive cycles of two closely related sea urchin species, Strongylocentrotus droebachiensis (O.F. Muller) and Strongylocentrotus pallidus (G.O. Sars). Sarsia 68:157-164

> Gaylord B, Gaines SD (2000) Temperature or transport? Range limits in marine species mediated solely by flow. Am Nat 155:769-789

Grieg JA (1928) The Folden Fjord. Echinodermata. Tromsø Museums Skrifter 1:1-12

$>$ Hagen NT (1995) Recurrent destructive grazing of successionally immature kelp forest by green sea urchins in Vestfjorden, Northern Norway. Mar Ecol Prog Ser 123: 95-106

Harley CDG, Hughes AR, Hultgren KM, Miner BG and others (2006) The impacts of climate change in coastal marine systems. Ecol Lett 9:228-241

Harrold C, Pearce JS (1987) The ecological role of echinoderms in kelp forests. In: Jangoux M, Lawrence JM (eds) Echinoderm studies, Vol 2. Balkema, Rotterdam, p 137-233

Hart MW, Scheibling RE (1988) Heat waves, baby booms, and the destruction of kelp beds by sea urchins. Mar Biol 99:167-176

Hereu B, Zabala M, Linares C, Sala E (2004) Temporal and spatial variability in settlement of the sea urchin Paracentrotus lividus in the NW Mediterranean. Mar Biol 144:1011-1018

Hernández JC, Brito A, Cubero E, Garcia N, Girard D, Gonzalez-Lorenzo G, Falcon JM (2006) Temporal patterns of larval settlement of Diadema antillarum (Echinodermata: Echinoidea) in the Canary Islands using an experimental larval collector. Bull Mar Sci 78:271-279

Hernández JC, Clemente S, Girard D, Pérez-Ruzafa A, Brito A (2010) Effect of temperature on settlement and postsettlement survival in a barrens-forming sea urchin. Mar Ecol Prog Ser 413:69-80

> Himmelman JH (1975) Phytoplankton as a stimulus for spawning in three marine invertebrates. J Exp Mar Biol Ecol 20:199-214

> Himmelman JH (1978) Reproductive cycle of the green sea urchin, Strongylocentrotus droebachiensis. Can J Zool 56:1828-1836
Himmelman JH (1986) Population biology of green sea urchins on rocky barrens. Mar Ecol Prog Ser 33:295-306

- Himmelman JH, Steele DH (1971) Foods and predators of green sea urchin Strongylocentrotus droebachiensis in Newfoundland waters. Mar Biol 9:315-322

Himmelman JH, Lavergne Y, Axelsen F, Cardinal A, Bourget E (1983) Sea urchins in the Saint-Lawrence estuary: their abundance, size structure, and sustainability for commercial exploitation. Can J Fish Aquat Sci 40: 474-486

Himmelman JH, Dumont CP, Gaymer CF, Vallières C, Drolet D (2008) Spawning synchrony and aggregative behaviour of cold-water echinoderms during multi-species mass spawnings. Mar Ecol Prog Ser 361:161-168

Hjorleifsson E, Kaasa O, Gunnarsson K (1995) Grazing of kelp by green sea urchin in Eyjafjordur, North Iceland. In: Skjoldal HR, Hopkins C, Erikstad KE, Leinaas HP (eds) Ecology of fjords and coastal waters. Elsevier Science, Amsterdam, p 593-597

$>$ Hughes L (2000) Biological consequences of global warming: is the signal already apparent? Trends Ecol Evol 15: 56-61

$>$ Hunt HL, Scheibling RE (1997) Role of early post-settlement mortality in recruitment of benthic marine invertebrates. Mar Ecol Prog Ser 155:269-301

Institute of Marine Research (2007) The Norwegian coastal current: oceanography and climate. Tapir Academic Press, Trondheim

Kain JM, Jones NS (1971) Biology of Laminaria hyperborea VI. Some Norwegian populations. J Mar Biol Assoc UK 51:387-408

> Keats DW, Steele DH, South GR (1984) Depth-dependent reproductive output of the green sea urchin, Strongylocentrotus droebachiensis (Muller, O.F.), in relation to the nature and availability of food. J Exp Mar Biol Ecol 80: 77-91

Kelly JR, Krumhansl KA, Scheibling RE (2012) Drift algal subsidies to sea urchins in low-productivity habitats. Mar Ecol Prog Ser 452:145-157

- Lamare MD (1998) Origin and transport of larvae of the sea urchin Evechinus chloroticus (Echinodermata: Echinoidea) in a New Zealand fiord. Mar Ecol Prog Ser 174: $107-121$

Lambert DM, Harris LG (2000) Larval settlement of the green sea urchin, Stronglyocentrotus droebachiensis, in the southern Gulf of Maine. Invertebr Biol 119:403-409

Lauzon-Guay JS, Scheibling RE (2007) Seasonal variation in movement, aggregation and destructive grazing of the green sea urchin (Strongylocentrotus droebachiensis) in relation to wave action and sea temperature. Mar Biol 151:2109-2118

Lawrence JM (1975) On the relationships between marine plants and sea urchins. Oceanogr Mar Biol Annu Rev 13: 213-286

> Leinaas HP, Christie H (1996) Effects of removing sea urchins (Strongylocentrotus droebachiensis): stability of the barren state and succession of kelp forest recovery in the east Atlantic. Oecologia 105:524-536

Lessios HA, Robertson DR, Cubit JD (1984) Spread of Diadema mass mortality through the Caribbean. Science 226:335-337

Levitan DR (1988) Density-dependent size regulation and negative growth in the sea urchin Diadema antillarum Philippi. Oecologia 76:627-629

> Levitan DR, Sewell MA, Chia FS (1992) How distribution 
and abundance influence fertilization success in the sea urchin Strongylocentrotus franciscanus. Ecology 73: 248-254

Lindley JA, Kirby RR (2010) Climate-induced changes in the North Sea Decapoda over the last 60 years. Clim Res 42: $257-264$

Ling SD, Johnson CR, Frusher S, King CK (2008) Reproductive potential of a marine ecosystem engineer at the edge of a newly expanded range. Glob Change Biol 14: 907-915

Ling SD, Johnson CR, Frusher SD, Ridgway KR (2009) Overfishing reduces resilience of kelp beds to climate-driven catastrophic phase shift. Proc Natl Acad Sci USA 106: 22341-22345

Lissner AL (1983) Relationship of water motion to the shallow-water distribution and morphology of two species of sea urchins. J Mar Res 41:691-709

McEdward LR (1985) Effects of temperature on the body form, growth, electron-transport system activity, and development rate of an echinopluteus. J Exp Mar Biol Ecol 93:169-181

McKay KM, Heck KL Jr (2008) Presence of the Jonah crab Cancer borealis significantly reduces kelp consumption by the green sea urchin Strongylocentrotus droebachiensis. Mar Ecol Prog Ser 356:295-298

McNaught DC (1999) The indirect effects of macroalgae and micropredation on the post-settlement success of the green sea urchin in Maine. PhD dissertation, University of Maine, Orono, ME

> Meidel SK, Scheibling RE (1998) Annual reproductive cycle of the green sea urchin, Strongylocentrotus droebachiensis, in differing habitats in Nova Scotia, Canada. Mar Biol 131:461-478

Miller BA, Emlet RB (1997) Influence of nearshore hydrodynamics on larval abundance and settlement of sea urchins Strongylocentrotus franciscanus and S. purpuratus in the Oregon upwelling zone. Mar Ecol Prog Ser 148: 83-94

Norderhaug KM, Christie HC (2009) Sea urchin grazing and kelp re-vegetation in the NE Atlantic. Mar Biol Res 5: 515-528

> Norderhaug KM, Christie H, Rinde E (2002) Colonisation of kelp imitations by epiphyte and holdfast fauna; a study of mobility patterns. Mar Biol 141:965-973

Norderhaug KN, Christie H, Fossa JH, Fredriksen S (2005) Fish-macrofauna interactions in a kelp (Laminaria hyperborea) forest. J Mar Biol Assoc UK 85:1279-1286

> Parmesan C (2006) Ecological and evolutionary responses to recent climate change. Annu Rev Ecol Syst 37:637-669

> Pearce CM, Scheibling RE (1990) Induction of metamorphosis of larvae of the green sea urchin, Strongylocentrotus droebachiensis, by coralline red algae. Biol Bull 179: 304-311

> Pearce CM, Scheibling RE (1991) Effect of macroalgae, microbial films, and conspecifics on the induction of metamorphosis of the green sea urchin Strongylocentrotus droebachiensis (Muller). J Exp Mar Biol Ecol 147: 147-162

Pedrotti ML, Fenaux L (1992) Dispersal of echinoderm larvae in a geographical area marked by upwelling (Ligurian Sea, NW Mediterranean). Mar Ecol Prog Ser 86: 217-227

> Pennington JT (1985) The ecology of fertilization of echinoid eggs: the consequences of sperm dilution, adult aggregation, and synchronous spawning. Biol Bull 169:417-430
Pinheiro J, Bates D, DebRoy S, Sarkar D, R Development Core Team (2012) nlme: linear and nonlinear mixed effects models. R package version 3.1-103. Available at http://cran.r-project.org/web/packages/nlme/index.html

> Prado P, Tomas F, Pinna S, Farina S and others (2012) Habitat and scale shape the demographic fate of the keystone sea urchin Paracentrotus lividus in Mediterranean macrophyte communities. PLoS ONE 7:e35170

> Raymond BG, Scheibling RE (1987) Recruitment and growth of the sea urchin Strongylocentrotus droebachiensis (Müller) following mass mortalities off Nova Scotia, Canada. J Exp Mar Biol Ecol 108:31-54

> Rinde E, Sjøtun K (2005) Demographic variation in the kelp Laminaria hyperborea along a latitudinal gradient. Mar Biol 146:1051-1062

Rodríguez SR, Ojeda FP, Inestrosa NC (1993) Settlement of benthic marine invertebrates. Mar Ecol Prog Ser 97: 193-207

Rowley RJ (1989) Settlement and recruitment of sea urchins (Strongylocentrotus spp.) in a sea-urchin barren ground and a kelp bed: are populations regulated by settlement or post-settlement processes? Mar Biol 100:485-494

Roy A, Metaxas A, Daigle RM (2012) Changes in vertical distribution and aggregative behaviour in response to population density for larval sea urchins (Strongylocentrotus droebachiensis) and sea stars (Asterias rubens). Mar Ecol 33:194-204

> Scheibling RE (1986) Increased macroalgal abundance following mass mortalities of sea urchins (Strongylocentrotus droebachiensis) along the Atlantic coast of Nova Scotia. Oecologia 68:186-198

Scheibling RE (1996) The role of predation in regulating sea urchin populations in eastern Canada. Oceanol Acta 19: 421-430

Scheibling RE, Raymond BG (1990) Community dynamics on a subtidal cobble bed following mass mortalities of sea urchins. Mar Ecol Prog Ser 63:127-145

> Scheibling RE, Robinson MC (2008) Settlement behaviour and early post-settlement predation of the sea urchin Strongylocentrotus droebachiensis. J Exp Mar Biol Ecol 365:59-66

Scheibling RE, Hennigar AW, Balch T (1999) Destructive grazing, epiphytism, and disease: the dynamics of sea urchin-kelp interactions in Nova Scotia. Can J Fish Aquat Sci 56:2300-2314

> Schroeter SC, Dixon JD, Ebert TA, Rankin JV (1996) Effects of kelp forests Macrocystis pyrifera on the larval distribution and settlement of red and purple sea urchins Strongylocentrotus franciscanus and $S$. purpuratus. Mar Ecol Prog Ser 133:125-134

Sewell MA, Watson JC (1993) A 'source' for asteroid larvae?: recruitment of Pisaster ochraceus, Pycnopodia helianthoides and Dermasterias imbricata in Nootka Sound, British Columbia. Mar Biol 117:387-398

Siddon CE, Witman JD (2003) Influence of chronic, low-level hydrodynamic forces on subtidal community structure. Mar Ecol Prog Ser 261:99-110

Siddon CE, Witman JD (2004) Behavioral indirect interactions: multiple predator effects and prey switching in the rocky subtidal. Ecology 85:2938-2945

> Sivertsen K (1997) Geographic and environmental factors affecting the distribution of kelp beds and barren grounds and changes in biota associated with kelp reduction at sites along the Norwegian coast. Can J Fish Aquat Sci 54:2872-2887 
Sivertsen K (2006) Overgrazing of kelp beds along the coast of Norway. J Appl Phycol 18:599-610

Skadsheim A, Christie H, Leinaas HP (1995) Population reductions of Strongylocentrotus droebachiensis (Echinodermata) in Norway and the distribution of its endoparasite Echinomermella matsi (Nematoda). Mar Ecol Prog Ser 119:199-209

Starr M, Himmelman JH, Therriault JC (1990) Direct coupling of marine invertebrate spawning with phytoplakton blooms. Science 247:1071-1074

Steneck RS, Graham MH, Bourque BJ, Corbett D, Erlandson JM, Estes JA, Tegner MJ (2002) Kelp forest ecosystems: biodiversity, stability, resilience and future. Environ Conserv 29:436-459

Steneck RS, Vavrinec J, Leland AV (2004) Accelerating trophic-level dysfunction in kelp forest ecosystems of the western North Atlantic. Ecosystems 7:323-332

Steneck RS, Leland A, McNaught DC, Vavrinec J (2013) Ecosystem flips, locks, and feedbacks: the lasting effects of fisheries on Maine's kelp forest ecosystem. Bull Mar Sci 89:31-55

Stephens RE (1972) Studies on the development of the sea urchin Strongylocentrotus droebachiensis. I. Ecology and normal development. Biol Bull 142:132-144

Stien A, Leinaas HP, Halvorsen O, Christie H (1998) Population dynamics of the Echinomermella matsi (Nematoda)Strongylocentrotus droebachiensis (Echinoida) system: effects on host fecundity. Mar Ecol Prog Ser 163:193-201

Strathmann R (1978) Length of pelagic period in echinoderms with feeding larvae from Northeast Pacific. J Exp Mar Biol Ecol 34:23-27

Editorial responsibility: Peter Steinberg, Sydney, New South Wales, Australia
Tegner MJ (1989) The feasibility of enhancing red sea urchin, Strongylocentrotus franciscanus, stocks in California: an analysis of the options. Mar Fish Rev 51:1-22

Tegner MJ, Dayton PK (1981) Population structure, recruitment and mortality of two sea urchins (Strongylocentrotus francicanus and $S$. purpuratus) in a kelp forest. Mar Ecol Prog Ser 5:255-268

Turner VG (1965) Some aspects of development in two echinoids. Am Zool 5:198

$>$ Underwood AJ, Fairweather PG (1989) Supply-side ecology and benthic marine assemblages. Trends Ecol Evol 4: $16-20$

Vadas RL (1977) Preferential feeding: an optimization strategy in sea urchins. Ecol Monogr 47:337-371

Wahle RA, Peckham SH (1999) Density-related reproductive trade-offs in the green sea urchin, Strongylocentrotus droebachiensis. Mar Biol 134:127-137

Walther GR, Post E, Convey P, Menzel A and others (2002) Ecological responses to recent climate change. Nature 416:389-395

Witman JD (1985) Refuges, biological disturbance, and rocky subtidal community structure in New England. Ecol Monogr 55:421-445

Witman JD, Dayton PK (2000) Rocky subtidal communities. In: Bertness MD, Gaines SD, Hay ME (eds) Marine community ecology. Sinauer Associates, Sunderland, MA, p 339-366

> Woll AK, van der Meeren GI, Fossen I (2006) Spatial variation in abundance and catch composition of Cancer pagurus in Norwegian waters: biological reasoning and implications for assessment. ICES J Mar Sci 63:421-433

Submitted: September 18, 2012; Accepted: May 18, 2013 Proofs received from author(s): July 29, 2013 